\title{
Biological control of insect pests of strawberry (Fragaria $x$ ananassa Duch.) in Irapuato, Guanajuato, Mexico
}

\begin{abstract}
Strawberry is one of the main crops in the state of Guanajuato, Mexico. The main insect pests are: Tetranychus urticae (Koch.), Trialeurodes vaporariorum (Westwood) and, Chaetosiphon fragaefolii (Cockerell). In order to evaluate the impact of different natural enemies on these pests, two treatments were compared. The first treatment $\left(T_{1}\right)$ consisted in pesticide application, the second treatment $\left(\mathrm{T}_{2}\right)$ was composed of the liberation of two natural enemies of these insect pests: Chrysoperla carnea (Stephens) and Hippodamia convergens (Guérin-Méneville). Coriander (Coriandrumsativum L.) was planted on the side of the fields where the natural enemies were released. The adults of $T$. urticae were more abundant in $T_{1}$ than $T_{2}$, by contrast,there were lower number of nymphs and adults of Ch. fragaefolii in $\mathrm{T}_{1}$; nymphs and pupae of $T$. vaporariorum there were not significantly different between treatments. The populations of T. urticae and Ch. fragaefolii followed a similar pattern, appearing since the end of November and reaching a peak in April, whereas the population of $T$. vaporariorum showed three population peaks (December, February and June). The presence of $C$. carnea and $H$. covergens was similar between $T$. urticaeand T. vaporariorum, but significant and different with respect of $C h$. fragaefolii. The average number of T. urticae's eggs per leaf in the treatment with the release of natural enemies was of 130, compared with 1000 eggs/leaf in the conventional treatment. The population of whiteflies was lower in the biological control treatment. There was an effective pest control with the biocontrol treatment.
\end{abstract}

Keywords: Natural enemies, Tetranychus urticae, Chaetosiphon fragaefolii, Trialeurodesvaporariorum, Chrysoperla carnea, Hippodamia convergens
Volume 4 Issue 4 - 2020

\author{
MD Salas-Araiza,' OA Martínez-Jaime,' JA \\ Díaz-García, ${ }^{2}$ S Flores-Mejia, ${ }^{3}$ R Guzmán- \\ Mendoza,' E Salazar-Solís' \\ 'Universidad de Guanajuato, División de Ciencias de la Vida, \\ Campus Irapuato-Salamanca, Mexico \\ ${ }^{2}$ Universidad de Medellín, Faculty of Basic Science, Colombia \\ ${ }^{3}$ Centre de recherche sur les grains, Canada
}

\begin{abstract}
Correspondence: Manuel Darío Salas-Araiza.Universidad de Guanajuato, División de Ciencias de la Vida, Campus IrapuatoSalamanca, Ex-Hacienda "El Copal”, Km. 9, carretera IrapuatoSilao, C.P. 3682I, Irapuato, Guanajuato, México,

Tel +| 52462624 18 89, Email dariosalasaraza@hotmail.com
\end{abstract}

Received: July 30, 2020 | Published: August 17, 2020

\section{Introduction}

Worldwide, around 250,000 ha of strawberry, Fragaria $x$ ananassa (Duch.) (Rosaceae) are cultivated with a production of over 4 million tons. ${ }^{1}$ In the region known as "El Bajio", in Mexico, the surface cultivated with strawberry is of 7,500 ha. ${ }^{2}$ For the most part, the production is destined to the national market and in smaller proportion to the export market.

Tetranychus urticae (Koch) (Prostigmata: Tetranychidae)knowing as two spoted spider mite-is the most common strawberry pest in Mexico. ${ }^{3}$ Other important pests are: the strawberry aphid Chaetosiphon fragaefolii (Cockerell) (Hemiptera: Aphididae), a known vector of several strawberry viruses ${ }^{4}$ and the greenhouse whitefly, Trialeurodes vaporariorum (Westwood) (Hemiptera: Aleyrodidae). ${ }^{1}$ The control of these pests is done mainly through the application of insecticides, which has hindered their management, generating resistant populations, ${ }^{5}$ resulting in the need to use of alternative control methods; an alternative is the one suggested by Pelliser and Jabbour ${ }^{6}$ they pointed out that surrounding the crop with annual plants that produce flowers is a way to increase biodiversity and the number of beneficial insects, annual flower habitats had a larger number of open blooms and supported a greater abundance of parasitoids later in the growing season.

A very efficient predator for red spider control is the green lacewing, Chrysoperla carnea (Stephens) (Neuroptera: Chrysopidae). ${ }^{7}$ For example, Easterbrook et al. ${ }^{8}$ reported that larvae of $C$. carnea consumed up to 790 C. fragaefolii aphids during their development,
C. carnea also has used again to T. urticae. The convergent lady beetle, Hippodamia convergens (Guérin-Meneville) (Coleoptera: Coccinellidae) is another predator that feeds mainly of aphids at both the larval and adult stages and very effective against $T$. urticae, it is common in New World agroecosystems. ${ }^{9}$

Early detection of the presence of insects in crops is key to implement control strategies and avoid pest outbreaks. Population dynamic models can be used to predict the presence of the pests in the field, as well as when would be best to release biological control agents in the field to maximize their efficiency in controlling the pest-population. ${ }^{10}$ The objective of this research was to measure the impact of the release of two biological control agents (C. carnea and $H$. convergens) for the control of three insect pests in strawberry: the two-spotted spider mite, the greenhouse whitefly and the strawberry aphid, in the state of Guanajuato, Mexico. The fluctuations in the populations of both predators and pests were monitored throughout the period in which this experiment was carried out.

\section{Materials and methods}

\section{Study area}

The work was carried out in the town of Serrano $\left(20^{\circ} 47^{\prime} 36^{\prime \prime} \mathrm{N}\right.$, $101^{\circ} 23^{\prime} 52$ 'W), in the municipality of Irapuato, Guanajuato, Mexico. Two plots cultivated with strawberry (var. Camarosa) were used, one hectare each and separated $50 \mathrm{~m}$ from each other. The plantation was done in the month of September 2004 and all agricultural practices were carried out by the grower, following standard practices for the region. ${ }^{11}$ 


\section{Experimental plots}

The pest management of the first plot $\left(\mathrm{P}_{1}\right)$ was done with the application of the following products: AGRIMEC1.8\% CE: $100 \mathrm{ml} / 100$ lt water/ha (abamectin, Syngenta Mexico) on February 18 and 25 and March 25 of 2005; SAVEY 50 GD®350 g/ha (hexitiazox, Gowan Mexicana) on April 15, 2005 and OMITE 68.10\% CE: 1 lt/ha (propargite, Arysta Life science) plus Green soap of potassium salts of fatty acids (CUPROSA) on April 29, May 6 and 13 of 2005. No biological control agents were released nor band of plants serving as a refuge was established in or around this plot. The chemical applications were made downwind to avoid the carry.

The second plot $\left(\mathrm{P}_{2}\right)$, was surrounded with a band $(100 \mathrm{~cm}$ meters wide) of coriander plants, Coriandrum sativum L. (Apiaceae) serving as a refuge. There were two releases of insects for biological control: March $11^{\text {th }}, 2005$ for $H$. convergens (150 adults) and April 22 $2^{\text {nd }}, 2005$ for $C$. carnea (400 adults). The first were collected in an alfalfa field belongs to the University of Guanajuato in Irapuato; whereas the latter species came from Beneficial Organisms Laboratory of CESAVEG. All releases were made each $20 \mathrm{~m}$, at the middle day from the plot edges in downwind. This treatment was excluded from chemical applications using a plastic cloth.

\section{Data sampling}

Samples were taken weekly, from November 26, 2004 to July 8,2005 , taking 30 randomly placed tri-foliated leaves, cutting them at ground level and depositing them in hermetic (Ziploc $\left.{ }^{\circledR}\right)$ plastic bags. The samples were taken to the laboratory where, the number of eggs, nymphs and adults of T. urticae (Tu), C. fragaefolii (Cf); as well as nymphs and pupae of T. vaporariorum (Tv) were counted. To illustrate the population fluctuation over time, the population curves of the number of these insects were plotted (Figures 1-4). A yellow sticky-trap was placed for one week (May 6 to 13, 2005) in each of the plots to quantify the populations of $C$. carnea and H. convergens.

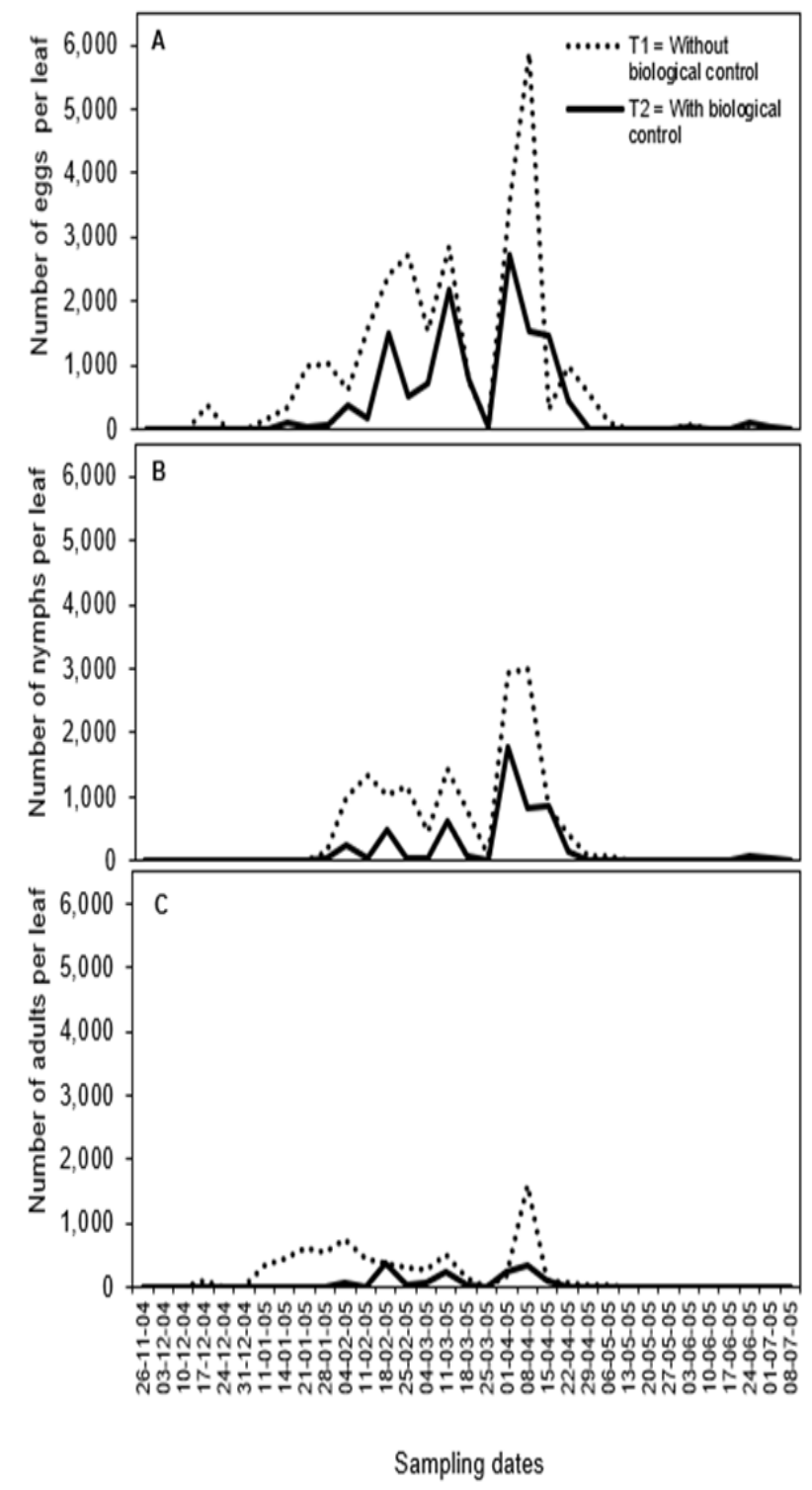

Figure I Population fluctuation of the eggs (A), nymphs (B) and adults (C) of Tetranychus urticae (Tu) in strawberry plots situated in Irapuato, Guanajuato (Mexico), without ( $T_{1}$, dashed line) and with ( $T_{2}$, continuous line) release of biological control populations: the convergent ladybeetle (Hippodamia convergens) and the green lacewing (Chrysoperla carnea). Dates of insecticides application in plot one:Agrimec 25/mar, 18 y 25/apr.; Savey: 15/abr; Omite 29/apr, 6 y I3/may; benefic insect release in the plot two: I50 adults of H.c. I I/mar, 400 adults of C.c. 22/apr. 


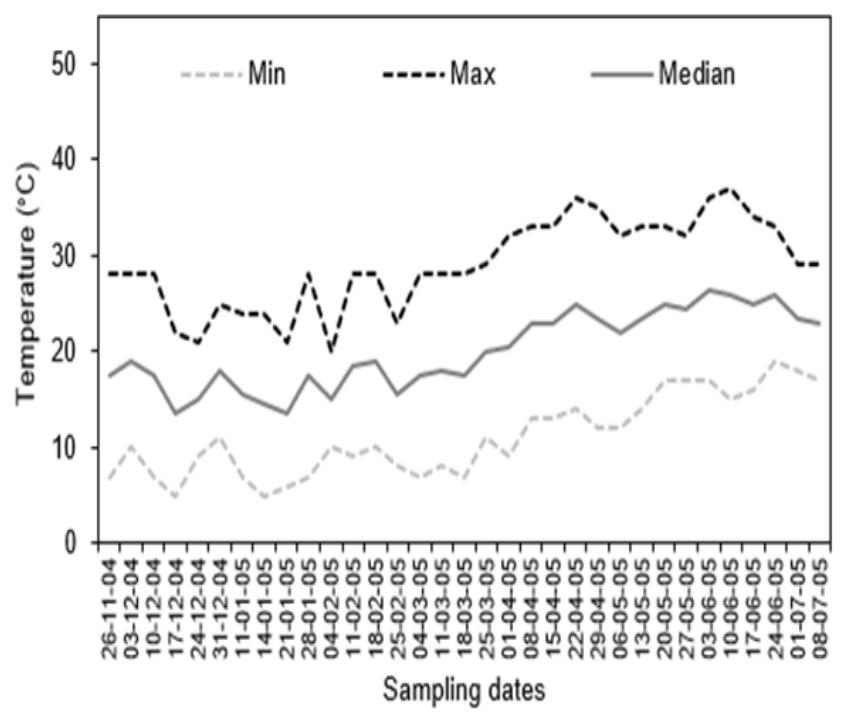

Figure 2 Minimal (gray dashed line), maximal (black dashed line) and median (gray continuous line) temperature $\left({ }^{\circ} \mathrm{C}\right.$ ) during the experimental period. Data gotten from meteorological stations network of the guanajuato produce foundation.

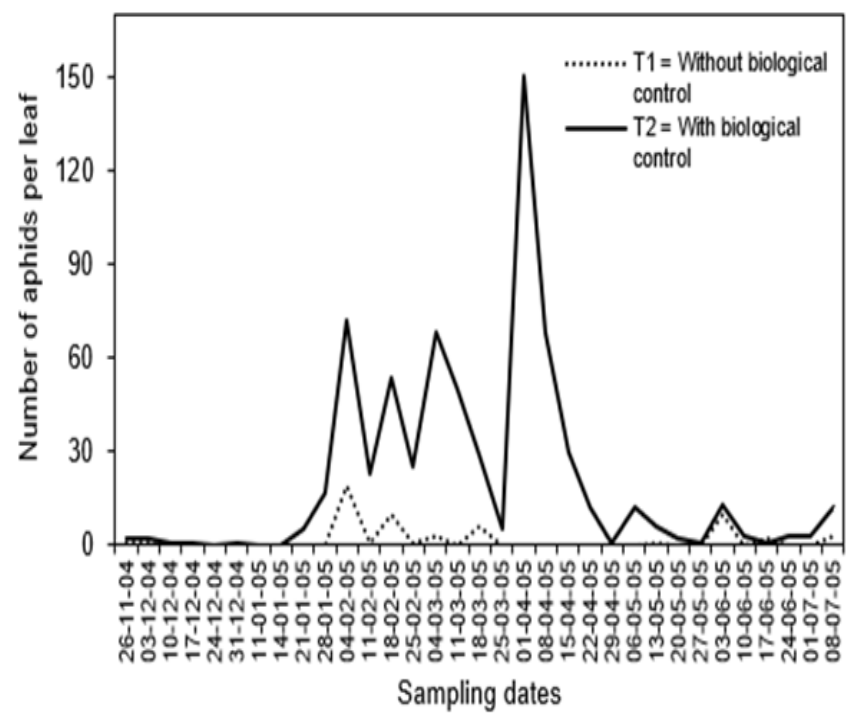

Figure 3 Population fluctuation of the strawberry aphid, Chaetosiphon fragaefolii (Cf), in strawberry plots situated in Irapuato, Guanajuato (Mexico), without $\left(T_{1}\right.$, dashed line) and with $\left(T_{2}\right.$, continuous line) release of biological control populations: the convergent ladybeetle (Hippodamia convergens) and the green lacewing (Chrysoperla carnea).

\section{Statistical analysis}

Two treatments were considered to evaluate their effect on insectpest populations: $\mathrm{T}_{1}=$ Conventional (chemical) control in plot $\mathrm{P}_{1}$ and $\mathrm{T}_{2}=$ Biological control in plot $\mathrm{P}_{2}$. The six pest populations considered (dependent variables) were: $\mathrm{Y}_{1}=$ whitefly nymph, $\mathrm{Y}_{2}=$ whitefly pupa, $\mathrm{Y}_{3}=$ aphids (both nymphs and adults), $\mathrm{Y}_{4}=$ two-spotted spider mite egg, $Y_{5}=$ two-spotted spider mite nymph and $Y_{6}=$ two-spotted spider mite adult.Due to the discreet nature of the data, a data transformation was applied using the formula: ${ }^{12}$

$$
\sqrt{Y_{i}+1}, i=1,2,3,4,5,6
$$

Subsequently, a test of independence was carried out in order to determine if the variables were ought to be analyzed using univariate or multivariate techniques, the latter considering the covariance between the study variables. ${ }^{13}$ The decision rule for the independence test considers the null hypothesis as
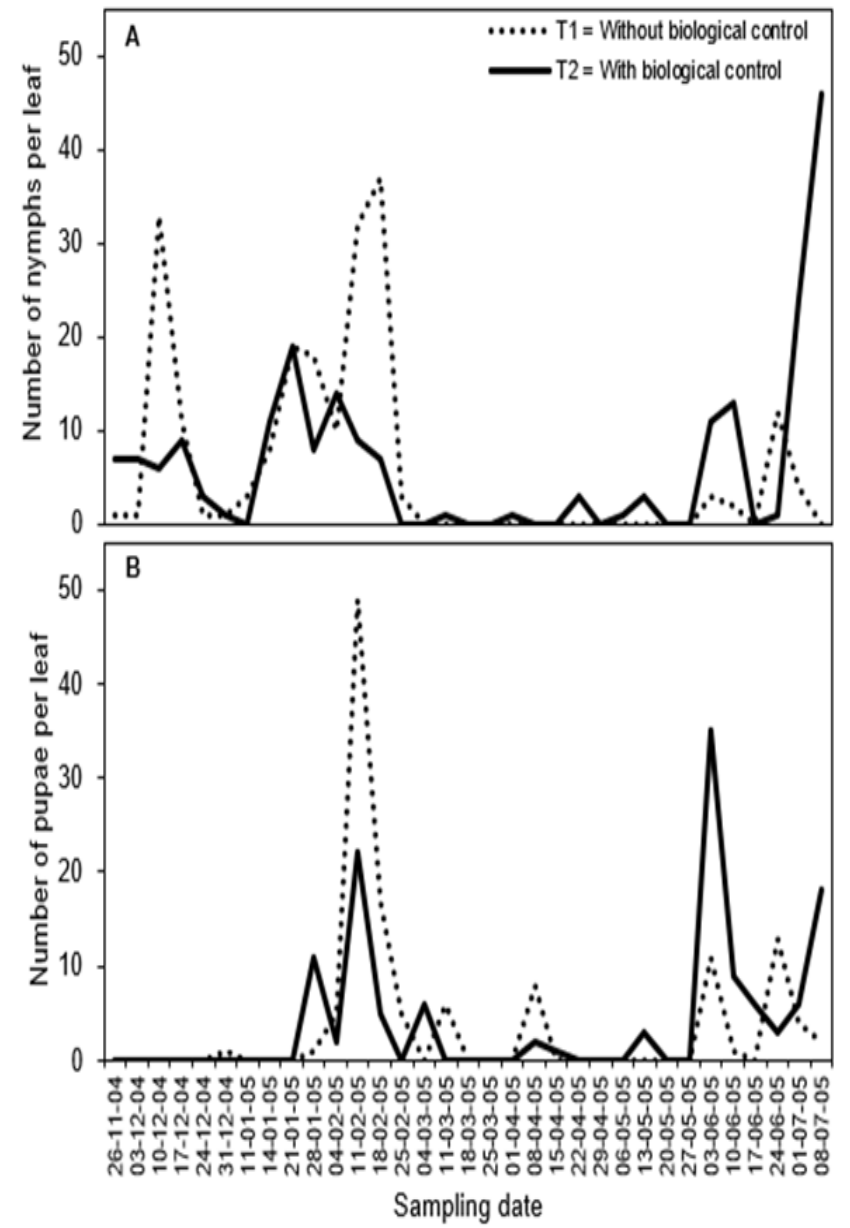

Figure 4 Population fluctuation nymphs (A) and pupae (B) of the greenhouse whitefly, Trialeurodes vaporariorum (Tv) in strawberry plots situated in Irapuato, Guanajuato (Mexico), without ( $T_{1}$, dashed line) and with ( $T_{2}$, continuous line) release of biological control populations: the convergent ladybeetle (Hippodamia convergens) and the green lacewing (Chrysoperla carnea).

$$
\mathrm{H}_{0}: O=\left[\begin{array}{cccc}
\sigma_{11} & 0 & \ldots & 0 \\
0 & \sigma_{22} & \ldots & 0 \\
\cdot & \cdot & & \cdot \\
\cdot & \cdot & & \cdot \\
\cdot & \cdot & & \cdot \\
0 & 0 & \ldots & \sigma_{p p}
\end{array}\right]
$$

The null hypothesis is rejected if the U-statistic value, or a corresponding specified probability value, where to be $U \geq \chi_{\alpha, f}^{2}$ where $\mathrm{U}$ is:

$$
U=-\left[v-\left(\frac{2 p+5}{6}\right)\right] \ln \mathrm{U}_{1}
$$

and $\mathrm{U}_{1}$ is:

$$
U_{1}=|R|
$$

Being $R$ the sample correlation matrix corresponding to $\mathrm{s}$, which is the sample variances and covariances matrix of the variables $Y_{1}, Y_{2}$, $\mathrm{Y}_{3}, \mathrm{Y}_{4}, \mathrm{Y}_{5}$ and $\mathrm{Y}_{6}$. The parameter $v$ represents the degrees of freedom of $\mathrm{s}$ and the parameter $\chi_{\dot{\boldsymbol{a}}, \boldsymbol{f}}^{2}$ ddenotes the percentile of a variable 
with chi-square distribution with $f$ degrees of freedom and level of significance $\boldsymbol{\alpha}$, where:

$$
f=\frac{p(p-1)}{2}
$$

With the purpose of establishing if there is a difference between the two treatments, the following null hypothesis was proposed, $\mathrm{H}_{0}: \grave{i}_{1}=\grave{i}_{2}$, in opposition to the alternative hypothesis, $\mathrm{H}_{1}: \mathbf{i}_{1} \neq \mathbf{i}_{2}$. These hypotheses establish the equality and difference between the vectors of treatment means, respectively, denoted in the following way:

$$
\mathbf{̀}_{1}=\left[\begin{array}{c}
\mu_{11} \\
\mu_{12} \\
\cdot \\
\cdot \\
\cdot \\
\mu_{1 p}
\end{array}\right] \text { and } \mathbf{i ̀}_{2}=\left[\begin{array}{c}
\mu_{21} \\
\mu_{22} \\
\cdot \\
\cdot \\
\cdot \\
\mu_{2 p}
\end{array}\right]
$$

This, if treatments $T_{1}$ and $T_{2}$ have sample sizes of $N_{1}$ and $N_{2}$, with vectors of sample means $\bar{Y}_{1}$ and $\bar{Y}_{2}$ and matrices of variancescovariances $\mathrm{S}_{1}$ and $\mathrm{S}_{2}$.

Then, applying the principles of union-intersection or the likelihood ratio to test the null hypothesis, we used the statistic known in the literature as Hotelling's T-square $\left(T^{2}\right),{ }^{12,13}$ whose expression is:

$$
\mathrm{T}^{2}=\frac{\mathrm{N}_{1} \mathrm{~N}_{2}}{\mathrm{~N}_{1}+\mathrm{N}_{2}}\left(\overline{\mathrm{Y}}_{1}-\overline{\mathrm{Y}}_{2}\right)^{T} \mathrm{~S}^{-1}\left(\overline{\mathrm{Y}}_{1}-\overline{\mathrm{Y}}_{2}\right)
$$

Where:

$\mathrm{N}_{1}$ and $\mathrm{N}_{2}$ are: Sample size

$\bar{Y}_{1}$ and $\bar{Y}_{2}$ are: mean of sample

$\mathrm{T}^{2}$ is: T-squared of Hotelling

and, where Scorresponds to:

$$
\begin{aligned}
& \mathrm{S}=\frac{\left(\mathrm{N}_{1}-1\right) \mathrm{S}_{1}+\left(\mathrm{N}_{2}-1\right) \mathrm{S}_{2}}{\mathrm{~N}_{1}+\mathrm{N}_{2}-2} \\
& F=\frac{N_{1}+N_{2}-p-1}{\left(N_{1}+N_{2}-2\right) p} \mathrm{~T}^{2}
\end{aligned}
$$

and follows the Snedecor's F-distribution with $p$ degrees of freedom in the numerator. The degrees of freedom in the denominator are determined by:

$$
\left(N_{1}+N_{2}-p-1\right)
$$

Then, the decision rule for a test with significance level $\alpha$ is to reject the $\mathrm{H}_{0}$ if:

$$
\boldsymbol{T}^{2} \geq \frac{\left(\boldsymbol{N}_{1}+\boldsymbol{N}_{2}-2\right) \boldsymbol{p}}{\boldsymbol{N}_{1}+N_{2}-\boldsymbol{p}-1} \mathrm{~F}_{\boldsymbol{a}: \boldsymbol{p},\left(N_{1}+N_{2}-\boldsymbol{p}-1\right)}
$$

If the $\mathrm{H}_{0}$ is rejected, then $\mu_{1 j} \neq \mu_{2 j}$ for at least one $j=1,2, \ldots, p$. There is no guarantee that any of the hypotheses $H_{0}: \mu_{1 j}=\mu_{2 j}$ will be rejected for some $j$ by applying some univariate test. So, for practical purposes it is possible to establish simultaneous confidence intervals applying the Bonferroni inequality. ${ }^{12,13}$ The simultaneous confidence intervals of Bonferroni with $100(1-\alpha) \%$ for the $p$ differences between means are:

$$
\mu_{1 j}-\mu_{2 j}:\left(\bar{Y}_{1 j}-\bar{Y}_{2 j}\right) \pm t_{\alpha / 2 p: N_{1}+N_{2}-2} \sqrt{\frac{N_{1}+N_{2}}{N_{1} N_{2}} s_{j j}}
$$

where, $S_{\mathrm{jj}}$ is the $\mathrm{jj}$-th element of the diagonal of the matrix $\mathbf{S}$, and $t_{\alpha / 2 p: N_{1}+N_{2}-2}$ is the $100(\alpha / 2 p)$-th highest percentile of a Student's t-distribution ( t ) with $N_{1}+N_{2}-2$ ) degrees of freedom.

Finally, by establishing the simultaneous confidence intervals for each possible difference in means, the decision rule to test the hypotheses $H_{0}: \mu_{1 j}=\mu_{2 j}$ for some $j$ is as follows: Reject $\mathrm{H}_{0}$ for some $j$, if both limits of the corresponding simultaneous interval are of the same sign. Alternatively, accept the $\mathrm{H}_{0}$ if the corresponding simultaneous confidence interval includes the zero value.

The partial correlation coefficients between the populations of the insect pests studied (transformed dependent variables $Y_{1}, Y_{2}$, $\mathrm{Y}_{3}, \mathrm{Y}_{4}, \mathrm{Y}_{5}$ and $\mathrm{Y}_{6}$ ) were also calculated in relation with different (independent) climate variables ( $\mathrm{y} 6=$ mean temperature for the time of fieldwork, and $\mathrm{X}_{2}=$ accumulated rainfall for the time of fieldwork). The software used was R. ${ }^{14}$

\section{Results and discussion}

The independence test applied to the transformed variables $Y_{1}, Y_{2}$, $\mathrm{Y}_{3}, \mathrm{Y}_{4}, \mathrm{Y}_{5}$ and $\mathrm{Y}_{6}$ yielded a value for the statistic $\mathrm{U}=239.3$ with a probability of $p<0.0001 * *$, concluding that the transformed variables are not independent and therefore it is necessary to use a multivariate analysis.

The value of the Hotelling's $\mathrm{T}^{2}$ between the means of the vectors of the $\mathrm{T}_{1}$ and $\mathrm{T}_{2}$ treatments was of 51.4 with a probability $p<=0.0001$ $* *$, thus rejecting the null hypothesis and implying that $\mu_{1 j} \neq \mu_{2 j}$ for at least one $j=1,2, \ldots, p$. In order to verify which variables presented differences between the treatment means showed in Table 1 , the Bonferroni results showed that there is no statistical difference between the means of the nymphs and pupae of the whitefly $\left(\mathrm{Y}_{1}\right.$ and $\mathrm{Y}_{2}$ ), and between the eggs and nymphs of the two-spotted spider mite $\left(\mathrm{Y}_{4}\right.$ and $\left.\mathrm{Y}_{5}\right)$ (Table 2). However, the means of the treatments were different for the aphids $\left(\mathrm{Y}_{3}\right)$ and adults of the two-spotted spider mite $\left(\mathrm{Y}_{6}\right)$.

The release of the biological control agents (convergent lady beetle and the green lacewing), along with the use of coriander as a refuge were associated with the reduced populations of the two-spotted spider mite(Tu) (Figure 1). This is consistent with the literature regarding the use of bio-control agents for the regulation of insect populations. For example, Delgado-Ramírez et al. ${ }^{15}$ highlighted the benefits of the use of predators for the regulation of aphid populations, such as the sugarcane aphid, Melanaphis sacchari (Zehntner) (Hemiptera: Aphididae).

It is also necessary to consider the effect of the predators on inter and intra-species populations. Khan \&Yoldas ${ }^{16}$ reported that Hippodamia variegata (Goeze) (Coleoptera: Coccinellidae), in the absence of prey, such as aphids, prefers feeding on coccinellid eggs, of both same (intra) and other (inter) species. The changes in the feeding preferences observed in this study might be related to the small size of larvae and eggs; as a consequence, adults of aphids and mites were depredated by convergent lady beetle and the green lacewing possibly the small size of the nymphs and eggs of Tu and Tv, cause their food preference to be directed towards larger individuals such as aphids and adults of the mite. 
Table I Transformed and original means of the number of individuals of six insect pests $\left(Y_{1}=\right.$ whitefly nymph, $Y_{2}=$ whitefly pupa, $Y_{3}=$ aphids (nymphs and adults), $Y_{4}=$ two-spotted spider mite egg, $Y_{5}=$ two-spotted spider mite nymph and $Y_{6}=$ two-spotted spider mite adult) for treatments without ( $\left.T_{1}\right)$ and with $\left(\mathrm{T}_{2}\right)$ biological control

\begin{tabular}{|c|c|c|c|c|c|c|}
\hline \multirow[t]{2}{*}{ Treatments } & \multicolumn{6}{|c|}{ Dependent variables } \\
\hline & $\mathbf{Y}_{1}$ & $\mathbf{Y}_{2}$ & $\mathbf{Y}_{3}$ & $\mathbf{Y}_{4}$ & $\mathbf{Y}_{5}$ & $\mathbf{Y}_{6}$ \\
\hline \multicolumn{7}{|c|}{ Transformed means } \\
\hline$T_{1}$ & 2.1389 & 1.7356 & $\mathrm{I} .44 \mathrm{I}$ & 19.7847 & 13.3866 & 10.4425 \\
\hline $\mathrm{T}_{2}$ & 2.2848 & 1.8196 & 3.6992 & 12.7247 & 7.6201 & 4.5574 \\
\hline \multicolumn{7}{|l|}{ Original means } \\
\hline $\mathrm{T}_{1}$ & 3.5747 & 2.0123 & 1.0766 & 390.4344 & $|78.201|$ & 108.0458 \\
\hline $\mathrm{T}_{2}$ & 4.2202 & 2.3109 & 12.684 & 160.918 & 57.0664 & 19.7696 \\
\hline
\end{tabular}

Table 2 Bonferroni simultaneous confidence intervals for the contrast of transformed means of the number of individuals of six insect pests $\left(Y_{1}=\right.$ whitefly nymph, $Y_{2}=$ whitefly pupa, $Y_{3}=$ aphids (nymphs and adults), $Y_{4}=$ two-spotted spider mite egg, $Y_{5}=$ two-spotted spider mite nymph and $Y_{6}=$ two-spotted spider mite adult) for treatments without $\left(T_{1}\right)$ and with $\left(T_{2}\right)$ biological control. The null hypothesis $\left(H_{0}: \mu_{1 j}=\mu_{2 j}\right)$ must be accepted if the simultaneous confidence interval includes the zero value. Alternatively, the $\mathrm{H}_{0}$ must be rejected if both limits of the corresponding simultaneous intervals are of the same sign

\begin{tabular}{|c|c|c|c|c|c|c|}
\hline \multirow[t]{2}{*}{ Treatments } & \multicolumn{6}{|c|}{ Dependent variables } \\
\hline & $\mathbf{Y}_{1}$ & $\mathbf{Y}_{2}$ & $\mathbf{Y}_{3}$ & $\mathbf{Y}_{4}$ & $\mathbf{Y}_{5}$ & $\mathbf{Y}_{6}$ \\
\hline Lower limit & $-1.16 \mid$ & -0.96 & -3.65 & -5.198 & -3.532 & 0.4 \\
\hline Upper limit & 0.869 & 0.792 & -0.866 & 19.318 & 15.065 & 11.37 \\
\hline
\end{tabular}

A well-designed biological control program should include an adequate selection of the natural enemies to be released as well as an appropriate time for their release. ${ }^{17}$ Releasing the biological control agents before the pest is present may significantly reduce the density of insect pests. The use of plants such as coriander around the plots, may provide refuge and act as an alternative food source (ex. pollen) that will significantly increase the survival of released biocontrol agents while prey populations are very low or absent in the field. ${ }^{18,19}$ These practices could be implemented in order to reduce the use of insecticides, causing a lower environmental impact and lower production costs. ${ }^{19}$ The use of generalist predators could be easier to implement and have a greater success in controlling a wide range of insect pests, as they do not depend in the presence of a specific host to be present in the field, as parasitoids do. ${ }^{20}$

\section{Population fluctuation of insect-pests}

\section{Tetranychus urticae (Tu)}

The population was present since the end of November at relative low rates. It is likely that the individuals of this population were originally from corn fields, Zea mays (L.) (Poaceae) surrounding the experimental plots. Corn is a natural host plant for $\mathrm{Tu}$, and the dispersion to contiguous fields occur naturally by the wind as well as human activity. ${ }^{21}$ By mid-February 2005 , the density of eggs and nymphs of Tu showed an increase (peak) (Figure 1A and 1B). While the adults also showed an increase, the peak (Figure 1C) was significantly small than those of the eggs and nymphs (Figure 1A and 1B). A second population peak was observed in the second week of March, abruptly decreasing for the next week, only to increase significantly and reach a maximum peak in the first week of April 2005. Following this peak, the populations (eggs, nymphs and adults) decreased significantly and never recovered for the rest of the season (Figure 1A, 1B and 1C). It is possible that the increase in temperature difficulted the development of the populations (Figure 2), Riahi et al. ${ }^{22}$ mentioned the temperature as the environmental factor with influence over acari development, they found that $25^{\circ} \mathrm{C}$ as optimal temperature for laying up to $40 \mathrm{eggs}$, while to $33^{\circ} \mathrm{C}$ the egg-laying goes down to 8 . Our observations coincide with that of the growers of the region, who consider the months of February, March and April as the most critical months for strawberry production, due to the significant increase of the populations of the two-spotted spider mite.

\section{Chaetosiphum fragaefolii (Cf)}

The strawberry aphid was present, although at very low levels, since November of 2004. The first population peak was observed in the second week of February of 2005 (Figure 3), followed by another in mid-February, early March and early April. This last one being the maximum peak for the population, after which the population diminished significantly. In California (U.S.A.), up to five population peaks have been observed in plots treated with pesticides, suggesting a high reproductive output. ${ }^{23}$ In this experiment the highest aphid number was observed in the plot with biological treatment. In contrast, Easterbrook et al. ${ }^{8}$ observed that the populations of $\mathrm{Cf}$ were significantly reduced when 8 larvae of the green lacewing $(C$. carnea) were liberated per strawberry plant. While the biological control treatments, were not as effective in controlling the strawberry aphid populations, their use for the control of the other pests, specially the two-spotted spider mite, was still important and could represent a viable alternative to the use of pesticides. This, specially, since up until now, in the state of Guanajuato, the damage caused by the strawberry aphid is not considered as important as the one by the twospotted spider mite. In the fieldwork, the aphids $C$. fragaefolii and Myzus persicae (Sulzer) were observed, but the first was the most abundant species. Other aphid species that have been observed in other strawberry production zones are: Rhodobium porosum (Sanderson) and Macrosiphum euphorbiae (Thomas) (Hemiptera: Aphididae) ${ }^{4}$ 


\section{Trialeurodes vaporariorum (Tv)}

Three population peaks of whitefly nymphs were observed in December 2004, mid-February and early June 2005 (Figure 4A). It is possible that the peak in December was caused by the adults that migrated from nearby fields, at the time cultivated with alfalfa, Medicago sativa (L.) (Fabaceae). There were two peaks of the pupae (the last developmental stage before adulthood), one in mid-February and another in early June (Figure 4B). Soto et al. ${ }^{24}$ mentioned that populations of T. vaporariorum completes its lifecycle in only 33 days at a temperature of $19^{\circ} \mathrm{C}$. In other locations, the management of this species is complicated, mainly due to its short lifecycle, its high reproductive output and its wide range of host-plants. In greenhouse production, the release of Encarsia formosa (Gahan) (Hymenoptera: Aphelinidae) is a common practice for the non-chemical control of T. vaporariorum. However, sometimes this is not enough for the control of the population and other management strategies must be implemented, such as the use of entomopathogenic fungi, such as Aschersonia aleyrodis (Deuteromycotina: Coelomycetes). ${ }^{25}$

\section{Influence of the climatic conditions}

In the plots without release of biological control agents, we found two significant partial negative correlations, the first between the adults of the Tu spider-mite $\left(\mathrm{Y}_{6}\right)$ and the average temperature $\left(\mathrm{X}_{1}\right)$, where the effect of the accumulated rainfall $\left(\mathrm{X}_{2}\right)$ remained fixed ( $\left.\mathrm{r}_{\mathrm{Y}_{6}} \mathrm{X}_{1} \bullet \mathrm{X}_{2}=-0.50, \mathrm{n}=33, \mathrm{P} 0.0071^{* *}\right)$. The second one was between the adults of the Tu spider-mite $\left(\mathrm{Y}_{6}\right)$ and the accumulated rainfall $\left(\mathrm{X}_{2}\right)$, when the average temperature $\left(\mathrm{X}_{1}\right)$ remained fixed $\left({ }^{\mathrm{Y}_{6}} \mathrm{X}_{2} \bullet \mathrm{X}_{1}=-0.45\right.$, $\left.\mathrm{n}=33, \mathrm{P}=0.0160^{*}\right)$. This indicates that adults of Tu increase when both climatic conditions (average temperature and accumulated rainfall) are reduced simultaneously, and in the absence of artificially released predators. When the high temperature reaches the threshold of metabolic activity can reduce it and cause catabolism. ${ }^{26}$ Furthermore, Riahi et al. ${ }^{22}$ observed that an increase in temperature reduces the female longevity.

In contrast, in the plots where biological control agents were released, we found significant partial (positive and negative) correlations between the average temperature $\left(\mathrm{X}_{1}\right)$ and the whitefly nymphs $\left(\mathrm{Y}_{1}, \mathrm{r}_{\mathrm{Y}_{1} \mathrm{X}_{1} \bullet \mathrm{x}_{2}}=-0.41, \mathrm{n}=33, \mathrm{P}=0.0294 *\right)$, whitefly pupae $\left(\mathrm{Y}_{2}\right.$, $\left.\mathrm{r}_{\mathrm{Y}_{2} \mathrm{X}_{1} \bullet \mathrm{X}_{2}}=0.53, \mathrm{n}=33, \mathrm{P}=0.0042 * *\right)$ and spider-mite nymphs $\left(\mathrm{Y}_{5}\right.$, $\left.\mathrm{r}_{\mathrm{Y}_{5} \mathrm{X}_{1} \bullet \mathrm{x}_{2}}=0.58, \mathrm{n}=33, \mathrm{P}=0.0013^{* *}\right)$, when the accumulated rainfall $\left(\mathrm{X}_{2}\right)$ remained fixed. Meaning that an increase in temperature causes an increase in the quantity of whitefly pupae $\left(\mathrm{Y}_{2}\right)$ and spider-mite nymphs $\left(\mathrm{Y}_{5}\right)$ but a decrease in whitefly nymphs $\left(\mathrm{Y}_{1}\right)$.

Analyzing the population dynamics of these insect-pests and the climatic factors influencing them allow to implement management strategies (i.e. scouting, release of bio-control agents, etc.) at the appropriate time and thus, reduce the use of pesticides or maximize their efficiency. A positive side-effect of reducing the amount of these insect-pests is the reduction of the presence of virus-transmitted diseases in the field. ${ }^{20}$

\section{Effect of the release of bio-control agents in the population dynamics of insect-pests}

In the case of the spider-mite $(\mathrm{Tu})$, where the bio-control agents were released (treatment $T_{2}$ ), there was a maximal density of 130 eggs/leaf (recorded on April $8^{\text {th }}$ 2005). In comparison, the same day, the treatment without bio-control agents (treatment $\mathrm{T}_{1}$ ), the amount of Tu eggs quantified per leaf was of $\sim 1000$ (Figure 1A). These results support the benefits of using bio-control agents, as well as the positive effects of strategies, such as the use of (coriander) refuge areas around the crop. In fact, the abundant presence of the Tu spider-mite in the $\mathrm{T}_{\text {, }}$ treatment caused the grower to abandon the field due to low yield that resulted, as well as the high cost that it would represent to control the population using pesticides.

The populations of the whitefly ( $\mathrm{Tv}$ ) were similar in both treatments $\left(\mathrm{T}_{1}\right.$ and $\left.\mathrm{T}_{2}\right)$. In contrast, the maximal population peak of the $\mathrm{Cf}$ aphid was observed in April $1^{\text {st }} 2005$, with $\sim 4$ individuals per leaf in the presence of bio-control agents $\left(\mathrm{T}_{2}\right)$, while in the absence of bio-cntrol agents $\left(\mathrm{T}_{1}\right)$, the maximum peak was observed in February $18^{\text {th }} 2005$ with only 0.35 individuals/leaf (Figure 3 ). It is possible that the high density of the Tu spider-mite has an influence on the development of the aphids by interfering in their feeding via the presence of the webs in the underside of the leaves. Thus, a plant without spider-mites would be more favourable to the presence of aphids.

The yellow sticky-traps that were installed at the center of the field after the release of the bio-control agents (May 6 to 13, 2005), showed that the fields were the bio-control agents were released (treatment $\mathrm{T}_{2}$ ), had a greater number of these bio-control agents $(C$. carnea and $H$. convergens), as well as other beneficial species such as Scymnus spp. and Paranaemia vittigera (Mannerheim) (Coleoptera:

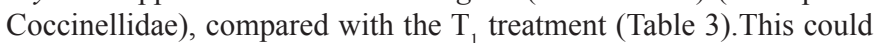
be, because the $T_{2}$ treatment included the coriander refuge bands around the experimental plot, which may have allowed the formation of more complex and diversified food webs than in the $\mathrm{T}_{1}$ treatment. $^{6}$

Guzmán-Mendoza et al. ${ }^{27}$ propose that the vegetal diversity has an important effect in organism interaction and in the functional composition of the populations. In our experiment, the establishment of a coriander band around the $\mathrm{P}_{1}$ treatment plot, not only may have attracted beneficial insects, but served as refuge and as an alternative source of nutriments for them. Dara et al. ${ }^{5}$ suggested the use of flower bands as refuge for natural enemies. Arnó et al. ${ }^{28}$ recommended the use of sweet alyssum (Lobularia maritima (L.), (Brassicaceae) for this purpose, as this plant offers nutriments and increases the survival and reproductive rates of parasitoids, thus helping establish their populations. They proposed that providing a mix of different flower species may be more advantageous over a single flower species, as the diversity may contribute to enhance the establishment of a broader guild of parasitoids, attracting more natural enemies as suggested by Albendín et al. ${ }^{29}$ \& Pellissier \& Jabbour et al. ${ }^{6}$

While generally, the release of $C$. carnea and $H$. convergens resulted in reduced numbers of insect pests, the release of bio-control agents of different species could not have the desired synergistic effect. Albendín et al. ${ }^{29}$ observed that in strawberry production, the release of several species of natural enemies did not showed additive effects and suggested that there was no advantage in releasing multiple natural enemies. In some cases, in the absence of prey, some predators, such as coccinellids, recur to cannibalism, either consuming their own eggs or those of other species of coccinellids. This was observed between H. convergens and Coccinella septempunctata (L.) (Coleoptera: Coccinellidae) by Khan \&Yoldas. ${ }^{16}$ Nonetheless, our results show that the presence of bio-control agents resulted in a general decrease in the populations of insect pests. Our results concur with Tuovinen $\&$ Lindqvist ${ }^{30}$ who concluded that the presence of natural enemies in strawberry production contribute to the control of Tu spider-mite and thrips. In addition, Greco et al. ${ }^{31}$ reported that Neoseiulus californicus (McGregor) (Acari: Phytoseiidae) is effective in controlling Tu spider-mite populations and could be included in an integrated pest management for strawberry production. 
Table 3 Beneficial insects captured in a week with yellow sticky-traps in strawberry fields in Guanajuato, Mexico (2005) with ( $\left.T_{2}\right)$ and without $\left(T_{1}\right)$ the release of biological control agents (C. carnea and H. convergens)

\begin{tabular}{|c|c|c|}
\hline Beneficial insect & $\begin{array}{l}\text { No. of individuals captured in } \mathrm{T}_{1} \\
\text { treatment }\end{array}$ & $\begin{array}{l}\text { No. of individuals captured in } \mathrm{T}_{2} \\
\text { treatment }\end{array}$ \\
\hline $\begin{array}{l}\text { C. carnea } \\
\text { (Neuroptera: Chrysopidae) }\end{array}$ & 4 & 27 \\
\hline $\begin{array}{l}\text { H. convergens } \\
\text { (Coleoptera: Coccinellidae) }\end{array}$ & 8 & 75 \\
\hline $\begin{array}{l}\text { Scymnusspp } \\
\text { (Coleoptera: Coccinellidae) }\end{array}$ & 5 & 14 \\
\hline $\begin{array}{l}\text { Collopsspp } \\
\text { (Coleoptera: Melyridae) }\end{array}$ & 3 & 15 \\
\hline $\begin{array}{l}\text { Stethorusspp } \\
\text { (Coleoptera: Coccinellidae) }\end{array}$ & 3 & 9 \\
\hline $\begin{array}{l}\text { Paranaemiavittigera } \\
\text { (Coleoptera: Coccinellidae) }\end{array}$ & 5 & 13 \\
\hline
\end{tabular}

Regardless, continuous monitoring is a key management practice for the control of the Tu spider-mite and other strawberry pests. It allows to detect the presence of these pests, to follow the evolution of their populations and to determine the moment for the release of biocontrol agents or pesticide applications that will have the most impact in controlling the pest populations in a cost-effective manner.

\section{Conclusion}

Our study allowed us to determine, that in the strawberry production zone of Irapuato, Guanajuato (Mexico), the critical period for the increase of the population of the two-spotted spider-mite (Tu) was between February and mid-April; while for the aphids (Cf) was from mid-February to mid-April, with a maximal peak at the beginning of April. In the case of the greenhouse whitefly (Tv), three population peaks were observed, with the biggest one happening in mid-February.

By describing the population fluctuations for these insectpests in strawberry production, our research will contribute to the development of pest monitoring and management programs, allowing for the reduction of both the use of pesticides and production costs.

The release of bio-control agents and the use of coriander bands as refuge and alternative sources of food, helped to establish their population and to diversify the predator/parasitoid guild by attracting other species of natural enemies.

The efficacy of the release of bio-control agents paired with the use of coriander bands for the control of different insect pests in strawberry was demonstrated by the reduction in the use of insecticides (zero applications) compared with the traditional production method (seven applications) resulting in a reduction in production costs.

\section{Acknowledgments}

None.

\section{Conflicts of interest}

Authors declare no conflict of interest exists

\section{References}

1. Martin RR, Tzanetakis IE. High risk strawberry viruses by region in the United States and Canada: implications for certification, nurseries and fruit production. Plant Diseases. 2013;97:1358-1362.

2. SIAP. Avances de siembras y cosechas. Resumen nacional por estado. 2018.

3. Gallardo-Granados S, E Salazar-Solís, MD Salas-Araiza, et al. Incidencia de especies de hemípteros en fresa bajo dos sistemas de cultivo en Irapuato, Guanajuato, México. Southwestern Entomologist. 2016;41(2):547-560.

4. AP Moreau DL, Fillmore SAE. Evaluation of strawberry for Chaetosiphon fragaefolii (strawberry aphid) preference. International Journal of Fruit Science. 2016;16:188-193.

5. Dara SK, Dara SR, Dara SS. Endophytic colonization and pest management potential of Beauberia bassiana in strawberries. Journal of Berry Reaserch. 2013;3:203-211.

6. Pellissier ME, Jabbour R. Herbivore and parasitoid insects respond differently to annual and perennial floral strips in an alfalfa ecosystem. Biological Control. 2018;123:28-35.

7. Reddy GVP. Plant volatiles mediate orientation and plant preference by the predator Chrysoper lacarnea Stephens (Neuroptera: Chrysopidae). Biological Control. 2002;25(1):49-56.

8. Easterbrook MA, Fitzgerald JD, Salomon MG. Suppression of aphids on strawberry by augmentative releases of larvae of the lacewing Chrysoperla carnea (Stephens). Biocontrol Science and Technology. 2006;16(9):893-900.

9. Pan H, Yang X, Siegfried BD, et al. A comprehensive selection of reference genes genes for RT-qPCR analisis in a predatory lady beetle, Hippodamia convergens (Coleoptera: Coccinellidae). PLoS ONE. 2015;10(4):1-15. 
10. Honek A, Martinkova Z, Saska P, et al. Aphids (Homoptera: Aphididae) on winter wheat: Prediction maximum abundance of Metopolophium dirhodum. Journal of Economic Entomology. 2018;111(4):1751-1759.

11. Salas-Araiza MD, Salazar-Solís E, Marín-Jarillo A. Manual para la determinación y control de Insectos Plaga de los Cultivos en El Bajío. Universidad de Guanajuato, Instituto Nacional de Investigaciones Forestales, Agrícolas y Pecuarias. Irapuato, Guanajuato, México. 2002. 141.

12. Johnson RA, Wichern DW. Applied multivariate statistical analysis. 6th ed. Prentice Hall, New Jersey. 1998;773.

13. Rencher AC. Methods of multivariate analysis. John Wiley \& Sons, New York, 2002;708.

14. $\mathrm{R}$ development core team $\mathrm{R}$. A language and environment for statistica computing. R foundation for statistical computing, vienna, AUT. 2008.

15. Delgado-Ramirez CS, Salas-Araiza MD, Martínez-Jaime OA, et al. Predation capability of Hippodamia convergens (Coleoptera: Coccinellidae) and Crysoper lacarnea (Neuroptera: Chrysopidae) feeding of Melanaphis sacchari (Hemiptera: Aphididae). Florida Entomologist. 2019;102(1):24-28.

16. Khan $\mathrm{MH}$, Yoldas Z. Intraguild predation between two aphidophagous coccinellids, Hippodamia variegata (G.) and Coccinella septempunctata L. (Coleoptera: Coccinellidae): the role of prey abundance. Biological Control. 2018;126:7-14.

17. Hoddle MM, Mace K, Steggall J. Proactive biological control: A costeffective management option for invasive pests. California Agriculture. 2018;72(3):148-150.

18. Pérez-Marcos M, López-Gallego E, Ramírez-Soria MJ, et al. Key parameters for the management and design of field margins aiming to the conservation of beneficial insects. Landscope management for functional biodiversity IOBC-WPRS Bulleti. 2017;122:151-155.

19. Miller TLP, Rebek EJ. Banker plants for aphid biological control in greenhouses. Journal of Integrated Pest Management. 2018; 9(1):9;1-8.

20. Leblanc A, Brodeur J. Estimating parasitoid impact on aphid populations in the field. Biological Control. 2018;119:33-42.

21. Gong YJ, Chen JC, Zhu L, et al. Preference and performance of twospotted mite Tetranychus urticae (Acari: Tetranychidae) on strawberry cultivars. Experimental and Applied Acarolog. 2018;76:185-196.
22. Riahi E, Shishehbor P, Nemati AR, et al. Temperature effects on development and life table parameters of Tetranychus urticae (Acari: Tetranychidae). Journal Agricultural Science Technology. 2013;15:661672.

23. Dara SK. Managing strawberry pests with chemical pesticides and non-chemical alternatives. International Journal of Fruit Science. 2016;16(1):129-141.

24. Soto GA, Apablaza J, Norero AS, et al. Requerimientos térmicos de Trialeurodes vaporariorum (Hemiptera: Aleyrodidae) en tomate (Lycopersicum esculentum). Ciencia e Investigación Agraria. 1999;26:37-42.

25. Fransen JJ, Winkelman K, van Lenteren JC. The differential mortality at various life stages of the greenhouse whitefly, Trialeurodes vaporariorum (Homoptera: Aleyrodidae), by infection with the fungus Aschersonia aleyrodis (Deuteromycotina: Coelomycetes). Journal of Invertebrate Pathology. 1987;50(2):158-165.

26. Sugawara R, Ullah MS, Ho ChCh, et al. Impact of temperature-mediated functional responses of Neosiulus womersleyi and N. longispinosus (Acari: Phytoseiidae) on Tetranychus urticae (Acari: Tetranychidae). Biological Control. 2018;126:26-35.

27. Guzmán-Mendoza R, Calzontzi-Marín J, Salas-Araiza MD, et al Diferenciación trófica de las comunidades de arañas e insectos en bosques reforestados del centro de México. Entomología Mexicana. 2017;4:519525 .

28. Arnó J, Oveja MF, R Gabarra. Selection of flowering plants to enhance the biological control of Tuta absoluta using parasitoids. Biological Control. 2018;122:41-50.

29. Albendín G, García N del C, Molina JM. Multiple natural enemies do not improve two spotted spider mite and flower western thrips control in strawberry tunnels. Chilean Journal of Agricultural Research. 2015;75(1):63-70.

30. Tuovinen T, Lindqvist I. Effect of introductions of a predator complex on spider mites and thrips in a tunnel and an open field of pesticide-free everbearer. Journal of Berry Research. 2015;4:203-216.

31. Greco NM, Liljesthröm GG, Gugole Ottaviano MF, et al. Pest management plan for the two-spotted spider mite, Tetranychus urticae, based on the natural occurrence of the predatory mite Neoseiulus californicus in strawberries. International Journal of Pest Management. 2011;57(4):299-308. 